THE JUSTICE OF CONTRADICTIONS 
This page intentionally left blank 


$$
\text { RICHARD L. HASEN }
$$

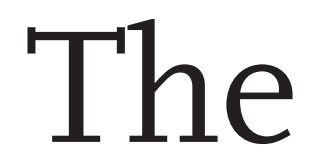

\title{
Justice of
}

Contradictions

\author{
ANTONIN SCALIA AND THE \\ POLITICS OF DISRUPTION
}

\author{
Yale
}

UNIVERSITY PRESS

NEW HAVEN\& LONDON 
Published with assistance from the Ralph S. Brown Memorial Publication Fund, and from the Mary Cady Tew Memorial Fund.

Copyright (C) 2018 by Richard L. Hasen.

All rights reserved.

This book may not be reproduced, in whole or in part, including illustrations, in any form (beyond that copying permitted by Sections Io7 and Io8 of the U.S. Copyright Law and except by reviewers for the public press), without written permission from the publishers.

Yale University Press books may be purchased in quantity for educational, business, or promotional use. For information, please e-mail sales.press@yale.edu (U.S. office) or sales@yaleup.co.uk (U.K. office).

Set in Scala and Scala Sans type by Integrated Publishing Solutions, Grand Rapids, Michigan.

Printed in the United States of America.

ISBN 978-0-300-22864-9 (hardcover : alk. paper) Library of Congress Control Number: 20I7952553

A catalogue record for this book is available from the British Library.

This paper meets the requirements of ANSI/NISO Z39.48-I992

(Permanence of Paper).

I0 $98765432 \mathrm{I}$ 
For Lori,

who continues to amaze, support, and inspire 
This page intentionally left blank 